\title{
NOTE
}

\section{Catfish hybrid Ictalurus punctatus $\times$ I. furcatus exhibits higher resistance to columnaris disease than the parental species}

\author{
Covadonga R. Arias ${ }^{1, *}$, Wenlong Cai ${ }^{1}$, Eric Peatman ${ }^{2}$, Stephen A. Bullard ${ }^{3}$ \\ ${ }^{1}$ Aquatic Microbiology Laboratory, Department of Fisheries and Allied Aquacultures, 253 Upchurch Hall, Auburn University, \\ Auburn, Alabama 36849, USA \\ ${ }^{2}$ Fish Genetics Laboratory, and ${ }^{3}$ Parasitology Laboratory, Department of Fisheries and Allied Aquacultures, \\ 203 Swingle Hall, Auburn University, Auburn, Alabama 36849, USA
}

\begin{abstract}
We present experimental data on susceptibility to columnaris disease, caused by the bacterium Flavobacterium columnare, in hybrid catfish (female channel catfish Ictalurus punctatus $\times$ male blue catfish $I$. furcatus) $(\mathrm{C} \times \mathrm{B})$. Under our experimental conditions, $\mathrm{C} \times \mathrm{B}$ hybrids were significantly more resistant to columnaris disease caused by the highly virulent strain of F. columnare BGFS-27 (genomovar II) than channel catfish and blue catfish. Channel and blue catfish cumulative mortalities after immersion challenge were 74 and $87 \%$, respectively, whereas mortality in the $\mathrm{C} \times \mathrm{B}$ hybrid was $31 \%$. Susceptibility to the strain ARS-1 (genomovar I) was lower among all catfishes, although channel catfish was the least resistant species at $32 \%$ cumulative mortality. By contrast, $\mathrm{C} \times \mathrm{B}$ hybrid and blue catfishes were strongly resistant to the ARS-1 strain, with $<10 \%$ mortality. Our data suggest enhanced disease resistance of the $\mathrm{C} \times \mathrm{B}$ hybrid to columnaris disease.
\end{abstract}

KEY WORDS: Channel catfish $\cdot$ Blue catfish $\cdot$ Flavobacterium columnare

\section{INTRODUCTION}

Channel catfish Ictalurus punctactus is the most economically important cultured fish in the USA, accounting for $>60 \%$ of all US aquaculture production (www.ers.usda.gov/). Historically, one of the main factors limiting expansion and profitability of the channel catfish industry has been disease control (Wagner et al. 2002, USDA 2003). Current best management practices for the channel catfish industry include prophylactic measures such as vaccination and use of approved therapeutants after disease onset. In addition, improving disease resistance is a main target for genetic stock enhancement programs including strain selection, hybrids, and transgenics.
Hybrids have been investigated for $>40$ yr (Giudice 1966), but apparently only 1 cross (female channel catfish $\times$ male blue catfish Ictalurus furcatus, $\mathrm{C} \times \mathrm{B}$ ) has proved to exhibit better aquaculture performance than either of its parents (Dunham et al. 2008). Some of the superior characteristics exhibited by $\mathrm{C} \times \mathrm{B}$ hybrids are faster growth, better feed conversion ratios, tolerance to low oxygen $\left(1.0 \mathrm{mg} \mathrm{l}^{-1}\right)$, better harvestability by seining, and higher tolerance to crowding (Masser \& Dunham 1998, Dunham et al. 2008). Because of these positive traits, an increasing number of catfish producers have opted to grow $\mathrm{C} \times \mathrm{B}$ hybrids despite the additional costs associated with their production, which requires artificial spawning, in contrast to the pond spawning methods used for 
channel catfish (Masser \& Dunham 1998). Regarding disease susceptibility, the resistance of $\mathrm{C} \times \mathrm{B}$ hybrids to enteric septicemia of catfish (ESC) is intermediate between that of channel catfish and that of blue catfish (Wolters et al. 1996), but these hybrids show no difference in resistance to channel catfish virus $(\mathrm{CCV})$, proliferative gill disease (PGD), or freshwater white spot disease (caused by Ichthyophthirius multifiliis) (Bosworth et al. 2003, Silverstein et al. 2008, Xu et al. 2011).

No experimental data on susceptibility to columnaris disease in $\mathrm{C} \times \mathrm{B}$ hybrids and blue catfish has been published, but anecdotal observations by Dunham et al. (2008) suggest that $C \times B$ hybrids may be less susceptible to columnaris than blue catfish. Columnaris disease, caused by the Gram negative bacterium Flavobacterium columnare, is considered the second most important disease affecting the channel catfish industry after ESC. In the present study, we evaluated the susceptibility of $\mathrm{C} \times \mathrm{B}$ hybrid catfish to F. columnare as compared to both parental species.

\section{MATERIALS AND METHODS}

\section{Fish husbandry}

Marion strain channel catfish Ictalurus punctatus fingerlings (mean weight: $5.2 \pm 0.8 \mathrm{~g}$; mean length: $6.2 \pm 1.1 \mathrm{~cm}$ ), Rio Grande strain blue catfish $I$. furcatus fingerlings (mean weight: $5.8 \pm 0.9 \mathrm{~g}$; mean length: $6.7 \pm 0.9 \mathrm{~cm}$ ), and Marion $\times$ Rio Grande cross $\mathrm{C} \times \mathrm{B}$ hybrid catfish (mean weight: $5.0 \pm 0.9 \mathrm{~g}$; mean length: $6.0 \pm 0.7 \mathrm{~cm}$ ) were obtained from the Fish Genetics Research Unit (Auburn University, Alabama, USA). Each strain (Marion and Rio Grande) was represented by individuals from a single family. The hybrid cross was made using standard techniques (strip spawning of the channel female and sacrifice of the blue male to obtain testes). Each family of fish was reared in individual cells (small concrete enclosures) within the partitioned aquaculture system at Clemson University (South Carolina, USA). All cells were placed within a 2 acre pond and shared water by constant exchange through each cell by means of air-lift pumps and a paddle wheel. This rearing system delivers uniform exposure to water quality conditions and the pond microbial environment (Baumgarner et al. 2005). No disease-based mortality was recorded during the course of the fingerling grow-out. Upon arrival at Auburn University, fish were stocked into $37 \mathrm{l}$ aquaria at 15 fish per tank, acclimatized for $5 \mathrm{~d}$ before challenge, and fed daily to satiation with AQUAMAX Grower 400 (Purina Mills). Ten randomly selected individuals of each fish species were examined and proved culture negative for Flavobacterium columnare prior to stocking in the tanks. Each aquarium had an individual biofilter and an air stone. Water was checked daily to maintain established parameters (80 ppm alkalinity, $40 \mathrm{ppm}$ hardness, 0.1 ppt salinity, $27 \pm 1{ }^{\circ} \mathrm{C}, \mathrm{pH} 7.8 \pm 0.2$ [mean $\pm \mathrm{SE}$ ], and ammonia and nitrites nondetectable). Tanks were filled with artificial freshwater prepared using $0.97 \mathrm{~g}$ of $\mathrm{CaCO}_{3}, 2.26 \mathrm{~g}$ of $\mathrm{NaHCO}_{3}$, and $110 \mathrm{ml}$ of primary seasalt stock into 551 of deionized water. Seasalt stock was made using $340 \mathrm{~g}$ of Marine Salt (Seachem) in 101 of deionized water.

\section{Bacterial strains and challenge experiments}

Two previously characterized strains of Flavobacterium columnare, ARS-1 (genomovar I) and BGFS-27 (genomovar II), were used (Arias et al. 2004, OlivaresFuster et al. 2007b). A genomovar is defined as a genomic group that shows $<70 \%$ reassociation by DNA:DNA hybridization with other genomic group(s) within a nomenspecies but cannot be differentiated by phenotypic traits (Ursing et al. 1995). Up to 3 different genomovars have been described in the species F. columnare (Triyanto \& Wakabayashi 1999). Both strains were originally isolated from channel catfish, and experimental challenges have shown ARS-1 as a low virulence strain, while BGFS-27 has proved to be highly virulent in channel catfish (Shoemaker et al. 2008). Strains were routinely cultured in modified Shieh broth (Shoemaker et al. 2005) for $24 \mathrm{~h}$ at $26^{\circ} \mathrm{C}$ with gentle shaking. Stock suspensions of all isolates were made by supplementing $24 \mathrm{~h}$ cultures (grown in Shieh broth) with glycerol up to a final concentration of $20 \%$, and kept at $-80^{\circ} \mathrm{C}$ for long-term storage.

Two challenge experiments were conducted, one with each Flavobacterium columnare strain. Each experiment consisted of 3 treatments (channel, blue, and $\mathrm{C} \times \mathrm{B}$ hybrid catfish) and 3 unchallenged control treatments (channel, blue and $\mathrm{C} \times \mathrm{B}$ hybrid catfish). Each treatment consisted of 3 randomized replicates (tanks). The immersion challenge was carried out as described in Shoemaker et al. (2008), with approximately $5 \times 10^{6}$ colony-forming units (CFU) ml ${ }^{-1}$ of the pathogen in the immersion bath. Controls were exposed to modified Shieh broth without bacteria. After a 30 min challenge, fish were returned to their individual aquaria and monitored at $12 \mathrm{~h}$ intervals for 
abnormal behavior, loss of appetite, and mortality. Moribund fish were sampled for F. columnare following standard protocols (Thoesen 2004). Putative $F$. columnare colonies were confirmed by specific PCR (Welker et al. 2005) and ascribed to the corresponding genomovar according to Olivares-Fuster et al. (2007a). Experiments were terminated and fish were euthanized with a lethal dose of tricaine methanesulfonate (MS-222; $300 \mathrm{mg} \mathrm{l}^{-1}$ ) after no sign of disease had been observed for longer than $48 \mathrm{~h}$ and all remaining fish in the tank appeared healthy.

Mortality data were compared by ANOVA using the Duncan's multiple range test (SAS Institute) to determine significant differences $(p<0.05)$ between the means.

\section{RESULTS}

Acute columnaris disease was successfully induced in the 2 species of catfish (Ictalurus punctatus and $I$. furcatus) and their hybrid after challenge with either Flavobacterium columnare strain. Columnaris signs include the development of pale or discolored areas beneath the dorsal fin toward the pectoral fins and posteriad to the pelvic fin that, in most cases, evolved into typical saddleback lesions (Grizzle \& Rogers 1976, Bullard et al. 2011). Gross clinical signs were similar among $\mathrm{C} \times \mathrm{B}$ hybrids, channel catfish, and blue catfish, and F. columnare colonies were isolated and confirmed by PCR from all diseased fish. Table 1 summarizes the cumulative mortalities observed in all 3 catfish species. Challenge doses were $1.0 \times 10^{6}$ and $9.6 \times 10^{6} \mathrm{CFU} \mathrm{m}{ }^{-1}$ for BGFS-27 and ARS-1 strains, respectively. No mortality occurred in any of the unchallenged control tanks. Cumulative mean mortalities obtained with genomovar II strain BGFS27 were significantly lower in $\mathrm{C} \times \mathrm{B}$ hybrids $(31 \%)$ than in both parental species. Blue catfish appeared

Table 1. Cumulative percent mortality (means \pm SE) from $\mathrm{C} \times \mathrm{B}$ hybrid catfish and parental species, channel catfish Ictalurus punctatus and blue catfish I. furcatus after challenge with Flavobacterium columnare BGFS-27 (genomovar II) and ARS-1 (genomovar I) strains. Within a column, means followed by different superscript letters are significantly different $(\mathrm{p}<0.05)$

\begin{tabular}{|lcc|}
\hline Catfish species & $\begin{array}{c}\text { F. columnare } \\
\text { BGFS-27 }\end{array}$ & $\begin{array}{c}\text { F. columnare } \\
\text { ARS-1 }\end{array}$ \\
\hline C×B catfish hybrid & $31( \pm 7.7)^{\mathrm{a}}$ & $9( \pm 2.4)^{\mathrm{a}}$ \\
Channel catfish (Marion) & $74( \pm 5.2)^{\mathrm{b}}$ & $32( \pm 4.5)^{\mathrm{b}}$ \\
Blue catfish (Rio Grande) & $87( \pm 8.3)^{\mathrm{b}}$ & $4( \pm 2.8)^{\mathrm{a}}$ \\
\hline
\end{tabular}

as the most sensitive species to this strain, exhibiting a cumulative mortality of $87 \%$, although this value was not significantly different from the observed channel catfish mortality $(74 \%)$. Challenge with the genomovar I strain resulted in fish showing the clinical signs of columnaris disease but with a lower mortality rate in all 3 catfish species. Channel catfish was the most susceptible species to ARS-1, with a $32 \%$ cumulative mortality. Blue catfish and $\mathrm{C} \times \mathrm{B}$ hybrids were significantly less susceptible to ARS-1, showing minimal mortalities at 4 and $9 \%$, respectively.

Fig. 1 shows the mortality progression caused by Flavobacterium columnare strain BGFS-27 in all 3 species. Channel and blue catfish began dying within $48 \mathrm{~h}$ post-challenge, while no mortality was observed in $\mathrm{C} \times \mathrm{B}$ hybrids until Day 4 . Mortality was more severe in channel catfish than in blue catfish during the first $6 \mathrm{~d}$ post-challenge, but more blue catfish succumbed to columnaris disease by the end of the experiment. $\mathrm{C} \times \mathrm{B}$ hybrids experienced a longer incubation phase, and mortalities plateau at $31 \%$. Channel catfish was the most susceptible species to genomovar I strain ARS-1, with mortalities starting within $48 \mathrm{~h}$ post-challenge and reaching $32 \%$ by Day 14 (Fig. 2). Blue catfish and $\mathrm{C} \times \mathrm{B}$ hybrids were refractive to colonization by ARS-1, with no mortalities observed until Day 7. Blue catfish exhibited the highest survival rate of all species, but this was not significantly different from $\mathrm{C} \times \mathrm{B}$ hybrids. Both blue catfish and $\mathrm{C} \times \mathrm{B}$ hybrids were significantly more resistant to $F$. columnare genomovar I strain ARS-1 than channel catfish.

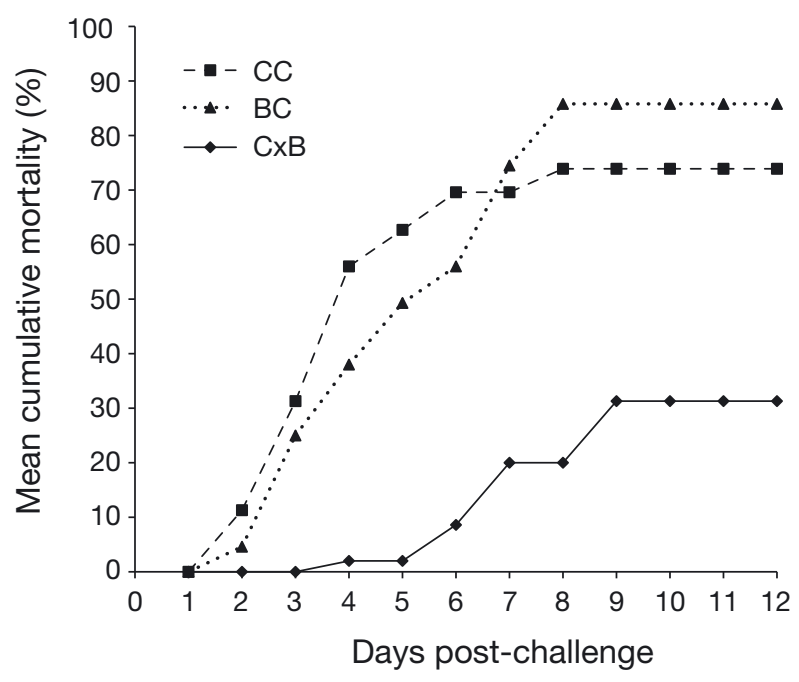

Fig. 1. Mean cumulative mortality of channel catfish Ictalurus punctatus (CC), blue catfish I. furcatus (BC), and $\mathrm{C} \times \mathrm{B}$ hybrid catfishes following immersion challenge with Flavobacterium columnare BGFS-27 strain (genomovar II). Infectious dose was $1.0 \times 10^{6} \mathrm{CFU} \mathrm{ml}^{-1}$ 


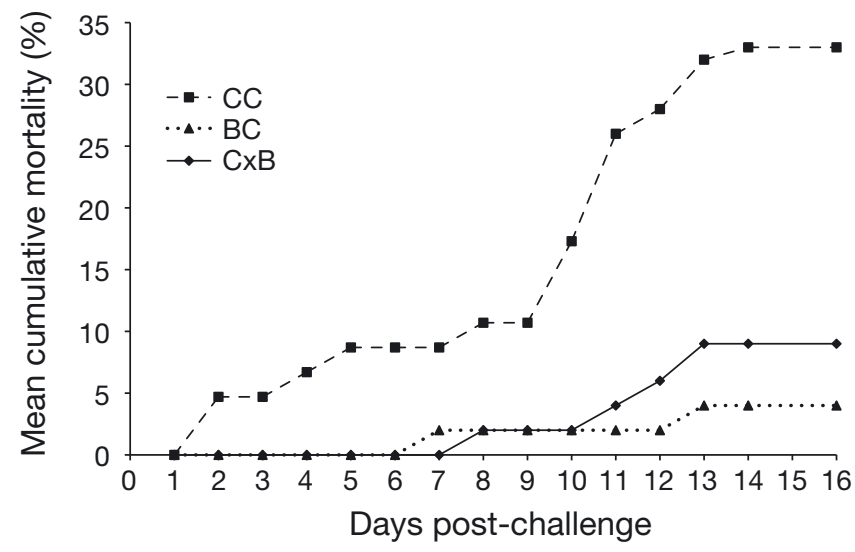

Fig. 2. Mean cumulative mortality of channel catfish Ictalurus punctatus (CC), blue catfish $I$. furcatus (BC), and $\mathrm{C} \times \mathrm{B}$ hybrid catfish following immersion challenge with Flavobacterium columnare ARS-1 strain (genomovar I). Infectious dose was $9.6 \times 10^{6} \mathrm{CFU} \mathrm{ml}^{-1}$

\section{DISCUSSION}

Our results show a significant difference in resistance to columnaris disease between 2 species of catfish (Ictalurus punctatus and I. furcatus) and their hybrid under experimental challenge conditions. This is the first study in which columnaris disease has been experimentally re-created in $\mathrm{C} \times \mathrm{B}$ hybrid and blue catfish. The $\mathrm{C} \times \mathrm{B}$ hybrid was more resistant to infection by Flavobacterium columnare BGFS-27 strain than both parental species, supporting the premise of hybrid vigor (Scribner et al. 2000). In a previous study, we showed a marked difference in virulence between strains of $F$. columnare genomovar I and II when we infected channel catfish by immersion (Shoemaker et al. 2008). We selected BGFS-27 as representative of genomovar II for the present study because it has been shown to attach and colonize channel catfish tissues at a higher rate than the ARS-1 strain (Olivares-Fuster et al. 2011). Originally isolated from wild channel catfish (Mobile River, Alabama, USA), BGFS-27 consistently achieves $>70 \%$ mortality in channel catfish in our challenge model (OlivaresFuster 2010). The mortalities observed in the present study were therefore expected for channel catfish. Mortalities in blue catfish and in channel catfish were not significantly different, both reaching $\sim 80 \%$. By contrast, onset of the disease in $\mathrm{C} \times \mathrm{B}$ hybrids lagged for $3 \mathrm{~d}$ and only reached $31 \%$ mortality.

Results obtained with the genomovar I strain ARS-1 were markedly different. Previous studies have shown that ARS-1 can cause up to $46 \%$ mortality in channel catfish fry (Shoemaker et al. 2008), but $<40 \%$ in channel fingerlings (Shoemaker et al. 2011).
However, the high standard errors reported in those studies make comparisons difficult between ARS-1 virulence in channel catfish fry and fingerlings (Shoemaker et al. 2008, 2011). Under our challenge conditions, we typically obtained $30 \%$ mortality when challenging channel catfish fingerlings with ARS-1 (data not shown). In the present study, the cumulative mortality obtained with ARS-1 in channel catfish was within the expected values, while $\mathrm{C} \times \mathrm{B}$ hybrid susceptibility to ARS-1 was significantly lower than in channel catfish. Interestingly, blue catfish showed the lowest mortality when challenged with Flavobacterium columnare genomovar I strain ARS-1 (although not statistically significant from the cumulative mortality observed in the $\mathrm{C} \times \mathrm{B}$ hybrid). This result contradicts some published literature in which blue catfish is considered more susceptible to columnaris disease than channel catfish (Masser \& Dunham 1998, Dunham et al. 2008). However, these are both review papers in which no experimental data or primary references regarding blue catfish resistance to columnaris were provided. According to our data, blue catfish is equally or less susceptible to columnaris diseases than channel catfish, depending on the strain tested.

It is not surprising that Flavobacterium columnare genomovar II is highly virulent for both channel and blue catfish since this genomovar has been associated almost exclusively with these fish species in the wild (Olivares-Fuster et al. 2007b). Genomovar I has also been isolated from wild channel and blue catfish, but at a much lower rate (Olivares-Fuster et al. 2007b).

Our results emphasize the importance of testing $>1$ bacterial strain from the same bacterial species when conducting pathogenicity studies, since blue catfish can be considered highly susceptible or highly resistant to columnaris disease depending on the strain used for challenge. This is of particular importance with columnaris disease, since at least 2 markedly distinctive genetic groups exist (Decostere et al. 1999, Arias et al. 2004, Soto et al. 2008). Similarly, future examination of the susceptibility profiles of different strains of channel catfish, blue catfish, and their resulting hybrids to columnaris is needed to broaden our understanding regarding the contribution of fish strain to disease resistance. Challenges of different channel catfish strains with Edwardsiella ictaluri, for example, have revealed significant differences in survival rates among strains (Wolters et al. 1996).

Two main conclusions result from the present study. First, channel catfish were equally or more susceptible to columnaris disease compared to blue 
catfish. Second, the studied $\mathrm{C} \times \mathrm{B}$ hybrid outperformed both parental species when challenged with a highly virulent Flavobacterium columnare strain.

Acknowledgements. We thank Stacey LaFrentz for facilitating the immersion challenge and helping with fish husbandry. This work was supported in part by Alabama Agricultural Experiment Station HATCH funds awarded to Stephen A. Bullard, Covadonga R. Arias, and Eric Peatman (Auburn University) and by the USDA-ARS/Auburn University Specific Cooperative Agreement 'Prevention of Diseases of Farmed Raised Fish' and USDA-ARS CRIS Project No. 6420-32000-022-00D awarded to Covadonga R. Arias (Auburn University). Wenlong Cai thanks Shanghai Ocean University (Shanghai, China) for partially funding his graduate research assistantship.

\section{LITERATURE CITED}

Arias CR, Welker TL, Shoemaker CA, Abernathy JW, Klesius PH (2004) Genetic fingerprinting of Flavobacterium columnare isolates from cultured fish. J Appl Microbiol 97:421-428

Baumgarner BL, Schwedler TE, Eversole AG, Brune DE, Collier JA (2005) Production characteristics of channel catfish, Ictalurus punctatus stocked at two densities in the partitioned aquaculture system. J Appl Aquacult 17:75-83

Bosworth BG, Wise DJ, Terhune JS, Wolters WR (2003) Family and genetic group effects for resistance to proliferative gill disease in channel catfish, blue catfish, and channel catfish $\times$ blue channel backcross hybrids. Aquacult Res 34:569-573

> Bullard SA, McElwain A, Arias CR (2011) Scanning electron microscopy of 'saddleback' lesions associated with experimental infections of Flavobacterium columnare in channel catfish, Ictalurus punctatus (Siluriformes: Ictaluridae) and zebrafish, Danio rerio (Cypriniformes: Cyprinidae). J World Aquacult Soc 42:906-913

Decostere A, Haesebrouck F, Charlier G, Ducatelle R (1999) The association of Flavobacterium columnare strains of high and low virulence with gill tissue of black mollies (Poecilia sphenops). Vet Microbiol 67:287-298

> Dunham RA, Umali GM, Beam R, Kristanto AH, Trask M (2008) Comparison of production traits of the NWAC103 channel catfish, NWAC103 channel $\times$ blue hybrid catfish, Kansas select 21 channel catfish and blue catfish grown at commercial densities and exposed to natural bacterial epizootics. N Am J Aquac 70:98-106

> Giudice JJ (1966) Growth of a blue $\times$ channel catfish hybrid as compared to its parent species. Prog Fish Cult 28: 142-145

Grizzle JM, Rogers WA (1976) Anatomy and histology of the channel catfish. Agricultural Experiment Station, Auburn University Press, Auburn, AL

Masser M, Dunham R (1998) Production of hybrid catfish. Southern Regional Aquaculture Center 190, Stoneville, MS

Olivares-Fuster O (2010) Development, characterization and early evaluation of new modified live vaccines against columnaris disease. Auburn University Press, Auburn, AL

Olivares-Fuster O, Shoemaker CA, Klesius PH, Arias CR (2007a) Molecular typing of Flavobacterium columnare isolates by single stranded conformation polymorphism analysis. FEMS Microbiol Lett 269:63-69

Olivares-Fuster O, Baker JL, Terhune JS, Shoemaker CA, Klesius PH, Arias CR (2007b) Host-specific association between Flavobacterium columnare genomovars and fish species. Syst Appl Microbiol 30:624-633

Olivares-Fuster O, Bullard SA, McElwain A, Llosa MJ, Arias CR (2011) Adhesion dynamics of Flavobacterium columnare to channel catfish (Ictalurus punctatus) and zebrafish (Danio rerio) after immersion challenge. Dis Aquat Org 96:221-227

Scribner KT, Page KS, Bartron ML (2000) Hybridization in freshwater fishes: a review of case studies and cytonuclear methods of biological inference. Rev Fish Biol Fish 10:293-323

Shoemaker CA, Arias CR, Klesius PH, Welker TL (2005) Technique for identifying Flavobacterium columnare using whole-cell fatty acid profiles. J Aquat Anim Health $17: 267-274$

> Shoemaker CA, Olivares-Fuster O, Arias CR, Klesius PH (2008) Flavobacterium columnare genomovar influences mortality in channel catfish (Ictalurus punctatus). Vet Microbiol 127:353-359

Shoemaker CA, Klesius PH, Drennan JD, Evans JJ (2011) Efficacy of a modified live Flavobacterium columnare vaccine in fish. Fish Shellfish Immunol 30:304-308

Silverstein PS, Bosworth BG, Gaunt PS (2008) Differential susceptibility of blue catfish, Ictalurus furcatus (Valenciennes), channel catfish I. punctatus (Rafinesque), and blue $\times$ channel hybrids to channel catfish virus. J Fish Dis 31:77-79

Soto E, Mauel MJ, Karsi A, Lawrence ML (2008) Genetic and virulence characterization of Flavobacterium columnare from channel catfish (Ictalurus punctatus). J Appl Microbiol 104:1302-1310

Thoesen JC (2004) Suggested procedures for the detection and identification of certain finfish and shellfish pathogens. American Fisheries Society - Fish Health Section, Bethesda, MD

Triyanto K, Wakabayashi H (1999) Genotypic diversity of strains of Flavobacterium columnare from diseased fishes. Fish Pathol 34:65-71

Ursing JB, Rosello-Mora R, Garcia-Valdes E, Lalucat J (1995) Taxonomic note: a pragmatic approach to the nomenclature of phenotypic similar genomic groups. Int J Syst Bacteriol 45:604

USDA (United States Department of Agriculture) (2003) Part I: reference of fingerling catfish health and production practices in the United States. USDA, National Animal Health Monitoring System, Fort Collins, CO

- Wagner BA, Wise DJ, Khoo LH, Terhune JS (2002) The epidemiology of bacterial diseases in food-size channel catfish. J Aquat Anim Health 14:263-272

> Welker TL, Shoemaker CA, Arias CR, Klesius PH (2005) Transmission and detection of Flavobacterium columnare in channel catfish Ictalurus punctatus. Dis Aquat Org 63:129-138

Wolters WR, Wise DJ, Klesius PH (1996) Survival and antibody response of channel catfish, blue catfish, and channel catfish female $\times$ blue catfish male hybrids after exposure to Edwardsiella ictaluri. J Aquat Anim Health 8: 249-254

Xu DH, Klesius PH, Peatman E, Liu Z (2011) Susceptibility of channel catfish, blue catfish, and channel $\times$ blue catfish hybrid to Ichthyophthirius multifiliis. Aquaculture 311: $25-30$ 